\title{
Factors affecting the component community structure of haemoparasites in bank voles (Clethrionomys glareolus) from the Mazury Lake District region of Poland
}

\author{
A. BAJER ${ }^{1}$, A. PAWEŁCZYK ${ }^{1}$, J. M. BEHNKE ${ }^{2 *}$, F. S. GILBERT ${ }^{2}$ and E. SINS KI ${ }^{1}$ \\ ${ }^{1}$ Department of Parasitology, Institute of Zoology, University of Warszawa, ul.Krakowskie Przedmieście 26/28, \\ 00-927 Warszawa, Poland \\ ${ }^{2}$ School of Biological Sciences, University Park, University of Nottingham, Nottingham NG7 2RD, UK
}

(Received 22 March 2000; revised 19 Fuly 2000; accepted 30 Fuly 2000)

SUMMARY

The prevalence and abundance of infections with haemoparasites were studied over a 3 year period in Clethrionomys glareolus (bank vole, $n=420$ ) sampled from forests in the NE of Poland. Total species richness was 5 (Prevalence $=$ Haemobartonella sp. $63.1 \%$, Bartonella grahamii $27.4 \%$, Hepatozoon erhardovae $31.4 \%$, Trypanosoma evotomys $15 \%$ and Babesia microti $1.0 \%$ ) with $81.9 \%$ of the voles carrying at least 1 species and a mean infracommunity species richness of 1.4. Variation in species richness was determined primarily by season and year, and the interaction of these factors. The observed frequency distribution of infracommunity species richness did not differ from that predicted by a null model, suggesting that there were no marked associations between the species. Analyses of prevalence and abundance of infection with each species in turn, revealed that overall the principal causes of variation were temporal and seasonal and their interaction, intrinsic factors such as age and sex playing only a minor role. However, the relative importance of specific extrinsic, and rarely intrinsic, factors varied and was distinct for each of the species in the study. Prevalence data revealed 4 sets of 2-way associations between species, mostly varyingly dependent on combinations of intrinsic and extrinsic factors. Analysis of quantitative associations suggested 4 sets of positive 2-way interactions, 3 of which remained after controlling for the effect of extrinsic and intrinsic factors on the abundance of each species, but only one could be unequivocally accepted (Haemobartonella sp. + B. grahamii) after correction for multiple comparisons. These data are discussed in the context of the changing ecological profiles in this region of Eastern Europe and, in a wider context, in relation to current understanding of the factors which shape component community structures of haemoparasites in wild rodents.

Key words: bank vole, Clethrionomys glareolus, Babesia microti, Bartonella grahamii, Haemobartonella, Hepatozoon erhardovae, Trypanosoma evotomys, component community, haemoparasites, co-occurrence.

\section{INTRODUCTION}

Published studies on the component communities of haemoparasites in European wild rodents are mostly based on data collected in western, northern and southern Europe (Healing, 1981; Turner, 1986; Santos-Gomez et al. 1993; Wiger, 1979). There is comparatively little information on naturally occurring haemoparasites of wild rodents from eastern Europe (see Baker, Chitty \& Phipps, 1963; Sebek, 1978; Sebek, Rosicky \& Sixl, 1977; Walter \& Liebisch, 1980; Karbowiak \& Sinski, 1996a, $b$; Karbowiak et al. 1999), and in a broader context few studies have comprehensively evaluated the contribution of intrinsic and extrinsic factors in structuring these communities.

As part of a long-term study of parasite communities in wild rodents in the northeastern region of Poland, we collected data on blood parasites,

* Corresponding author: School of Biological Sciences, University Park, University of Nottingham, Nottingham NG7 2RD, UK. Tel: +0115951 3208. Fax: +0115951 3252. E-mail: jerzy.behnke@nottingham.ac.uk including both protozoan and bacterial infections, over a period of 3 years. The Mazury lake district region of Poland is of interest because many of the collective farms, which comprised intensively cultivated and enriched agricultural land, were abandoned following political changes in the early 1990 s. Much of this land is now reverting to nature, and natural succession has given rise to extensive, naturally seeded, young woodland. These ecological changes in the region are being documented (Rogozinska, 1997) and studied from various perspectives, not least regarding disease implications for local communities and visitors from urban centres. There are important consequences for human health from the increasing wild rodent populations because Lyme disease is present and increasing numbers of tourists are visiting the region for recreational purposes (Sinski \& Pawełczyk, 1999).

Over a 3-year period, and in specific seasons, we systematically sampled rodent populations in a study site that covered both abandoned farmland and the surrounding forests. In this paper we report on the blood parasite communities of the bank vole (Clethrionomys glareolus), which is numerically the 
dominant rodent species inhabiting the forest part of our study site. We evaluate the role of intrinsic (host age and sex) and extrinsic (year and season) factors in structuring the component community of haemoparasites and in influencing both prevalence and abundance of each of the species involved. Finally, we determine the extent to which co-occurring species interact with each other.

\section{MATERIALS AND METHODS}

\section{Study sites}

Our study site was located east of the nature reserve surrounding Lake Luknajno, and north of Lake Śniardwy, near the town of Mikołajki in the Mazury lake district region of NE Poland. Trapping was conducted in mature woodland with Scots pine (Pinus sylvestris), oak (Quercus robur), Norway spruce (Picea abies), silver birch (Betula verucosa) and common alder (Alnus glutinosa) as the dominant trees, forming a high canopy over the entire site. The dominant undergrowth was hazel (Corylus avellana) and ground cover comprised mostly Oxalis acetosella, Convalaria mayalis and Stellaria holostea.

\section{Collection of mice}

Rodents were caught live in locally constructed wooden traps, with a small metal platform internally which, when triggered, released a metal door. These were set out at $15 \mathrm{~m}$ intervals in parallel lines, $10 \mathrm{~m}$ either side of a track running through the woodland site. Trapping sessions comprised a minimum of 4 days, with traps being inspected in the early morning and just before dusk. Fresh traps replaced any traps containing animals and the animals were brought to the University of Warszawa's field station at Urwitalt. Visits to the study sites varied, but generally comprised at least a 4 day duration, at approximately 4 week intervals from late March until mid-November. For both practical and animal welfare reasons, it was not possible to visit the sites in the period between November and March because the ground was mostly hard frozen and deep snow covered our sites for most of the winter period. The months between March and November were divided into 3 seasons, comprising spring (March to early June), summer (late June to August) and autumn (September to November).

\section{Sampling of hosts}

At the field station in Urwitałt, all animals were inspected, identified, sexed, relevant morphometric data were recorded and they were weighed (to the nearest $0.5 \mathrm{~g}$ ). Ectoparasites were removed from the ears and limbs (mostly larval and nymph ticks and some mites) and the fur was inspected carefully for fleas. Thin blood smears were prepared from drops of blood taken from the tail vein. After inspection most animals were marked and released as near as possible to the original site of capture, whilst others were killed for recovery of endoparasites (data to be published elsewhere).

Blood smears were air-dried, fixed in absolute methanol, stained for $45 \mathrm{~min}$ in Giemsa's stain (diluted 1:3) in buffer at $\mathrm{pH} 7 \cdot 2$ and were brought back to the Department of Parasitology at the University of Warszawa for examination. Each smear was examined under oil immersion (using an Olympus AX70 microscope). Initially, sufficient fields of vision were examined to enable up to 50 leukocytes to be inspected for the presence of $H$. erhardovae (approximately 200 fields of vision under $\times 100$ objective lens). Each field of vision was also examined for the presence of other species, although these were not quantified at this stage. If the blood smear revealed the presence of other species, during this initial phase of examination, an additional 1000 erythrocytes were inspected and the number of cells infected with B. grahamii, B. microti and Haemobartonella sp. were recorded and expressed as no. of infected cells/100 erythrocytes. The concentration of trypanosomes was also expressed per 100 erythrocytes.

Age classes were established on the basis of weight (Morris, 1971) and sexual development as described by Mazurkiewicz (1972). Age class 1 comprised immature, juvenile voles $<15 \mathrm{~g}$ in weight and approximately less than 1.5 months old. Age class 2 comprised young mature voles, $15-19.5 \mathrm{~g}$ in weight representing animals approximately $1.5-2.5$ months old. Age class 3 comprised adult voles, weighing $>19 \cdot 5 \mathrm{~g}$ and 2.5 months and older.

\section{Statistical analysis}

The frequency distribution of infracommunity species richness was tested for goodness of fit to the positive binomial distribution (assumption of the null model is a regular distribution), the Poisson distribution (assumption of the null model is a random distribution) and to the null model of Janovy et al. (1995) (assumption of the null model is that, in the absence of associations and interactions between species, the frequency distribution of infracommunity species richness is predicted by prevalence values). Goodness of fit in each case was tested by $\chi^{2}$.

Prevalence (percentage of animals infected) was analysed by maximum likelihood techniques based on log linear analysis of contingency tables, implemented by the software package, Statgraphics Version 7 . For each species in turn we entered prevalence of infection as a binary factor (infected $=1$, not infected =0) and then year (3 levels, 1997, 1998 and 1999), season (3 levels, spring, summer and autumn), 
host age (3 levels) and host sex (2 levels) as factors. Beginning with the most complex model, involving all possible main effects and interactions, those combinations not contributing significantly to explaining variation in the data were eliminated stepwise, beginning with the highest-level interaction. A minimum sufficient model was then obtained, for which the likelihood ratio of $\chi^{2}$ was not significant, indicating that the model was sufficient in explaining the data.

Quantitative data reflecting parasite abundance within hosts were expressed as geometric means because the data were highly overdispersed (Elliott, 1977; Dash, Hall \& Barger, 1988). In some cases arithmetic means and standard errors of the means are also provided. These means reflect the abundance of infection as defined by Margolis et al. (1982) and include all subjects within the specified group, infected and not infected, for which relevant data were available. The degree of aggregation in quantitative data was calculated by the Index of Dispersion ( $I=$ the variance to mean ratio) and the Index of Discrepancy $(D)$ as described by Poulin (1993) (a value of 0 indicates an even distribution of counts across all hosts and a value of 1 indicates all parasites aggregated in a single host). Frequency distributions of individual species were also tested for goodness of fit to negative binomial, positive binomial and Poisson models by $\chi^{2}$ as described by Elliott (1977) and the negative binomial exponent $k$ is given as appropriate.

Parasite abundance was analysed by GLIM (A statistical system for generalized linear interactive modeling; GLIM 4, PC version, Royal Statistical Society 1993) as described previously, using models with normal errors after normalization of the data by $\log 10(x+1)$ transformation (Crawley, 1993; Wilson \& Grenfell, 1997; Behnke et al. 1999). Year, season, host age and host sex (see above for levels) were entered as factors. For models with normal errors the change in deviance is divided by the scale parameter and the result divided by the change in degrees of freedom D.F. following each deletion, to give a variance ratio, $F$. Complex models are given in full ANOVA tables, but simpler models are summarized in the text and only $F$ values are presented. The residuals from all models were checked for approximately normal distribution.

Quantitative associations between parasites were examined by multiple correlation analysis (Spearman rank-order correlation test) of raw parasite data from animals carrying both of 2 species, in each of the possible 2-way combinations (excluding $B$. microti because of very low prevalence of this species). To avoid the risk of Type 1 errors we adopted the Dunn-Sidak correction, lowering the cut-off value of $P$, according to the number of comparisons implemented (Sokal \& Rohlf, 1981). We also examined the correlations between the residuals from minimum sufficient 3,2 or 1 -way ANOVAs, as appropriate for individual species, in order to control for established differences between the years, seasons, host age and sex.

\section{RESULTS}

\section{Clethrionomys glareolus}

A total of 420 C. glareolus were sampled in the 3 year period. The structure of the sampled host population by year, host sex and age is summarized in Table 1 . Host density was estimated to enable comparison of vole populations between the 3 years of the study. Vole numbers were expressed as the number of trapped voles divided by the product of the number of traps set and the duration of trapping hours (Table 2). In agreement with other studies (Alibhai \& Gipps, 1985) we observed the same seasonal pattern each year with vole density beginning low in spring (May) and then rising to peak in the autumn (September and November). However, despite some differences between the years and the trapping sessions in which a proportion of voles was culled, overall the population of $C$. glareolus remained relatively stable across the 3 years of our study.

\section{Total species richness in the component community}

Five species of blood parasites were recorded (Table 3 ) and 344 voles $(81.9 \%)$ carried at least 1 of these species. Haemobartonella sp. was the most common and $B$. microti the rarest.

\section{Frequency distribution of infracommunity species richness}

The observed distribution of infracommunity species richness, illustrated in Fig. 1, showed a good fit to the positive binomial $\left(\chi^{2}=0 \cdot 49,4\right.$ D.F., $P=$ $0.972)$ but not to the Poisson distribution $\left(\chi^{2}=21 \cdot 8\right.$, 4 D.F., $P=0 \cdot 0004)$. It was not significantly different from that predicted by the null model for interactions of parasite species in an assemblage (Janovy et al. 1995) and $\chi^{2}=6 \cdot 14$ (4 D.F., $P>0 \cdot 05$ ).

\section{Mean infracommunity species richness}

The overall mean number of species of blood parasites harboured per host was $1.4 \pm 0.05$ (s.E.M.), with a variance to mean ratio of 0.665 indicating a positive binomial distribution. Analysis of these data (4-way ANOVA in GLIM with normal errors and year, season, host age and sex as factors, and Fig. 2) revealed that only year and season played a significant role in determining infracommunity species richness. The main effect of season was highly significant $\left(F_{2,409}=15.039, P<0.001\right)$ and that of year was marginal $\left(F_{2,409}=3.014,0.05>P>0.025\right)$ 
Table 1. The structure of the sampled host population by year of capture, host sex and age

\begin{tabular}{|c|c|c|c|c|c|c|}
\hline \multirow[b]{2}{*}{ Year } & \multirow[b]{2}{*}{ Sex } & \multicolumn{3}{|l|}{ Age } & \multirow{2}{*}{$\begin{array}{l}\text { Total } \\
\text { by sex }\end{array}$} & \multirow{2}{*}{$\begin{array}{l}\text { Total } \\
\text { by yea }\end{array}$} \\
\hline & & 1 & 2 & 3 & & \\
\hline \multirow[t]{3}{*}{1997} & Male & 26 & 47 & 17 & 90 & \\
\hline & Female & 20 & 31 & 24 & 75 & \\
\hline & Combined & 46 & 78 & 41 & & 165 \\
\hline \multirow[t]{3}{*}{1998} & Male & 18 & 25 & 21 & 64 & \\
\hline & Female & 23 & 9 & 21 & 53 & \\
\hline & Combined & 41 & 34 & 42 & & 117 \\
\hline \multirow[t]{3}{*}{1999} & Male & 20 & 32 & 12 & 64 & \\
\hline & Female & 25 & 32 & 17 & 74 & \\
\hline & Combined & 45 & 64 & 29 & & 138 \\
\hline $\begin{array}{l}\text { Total } \\
\text { by age }\end{array}$ & & 132 & 176 & 112 & & \\
\hline
\end{tabular}

Table 2. Estimation of population density of voles in the study site

\begin{tabular}{lccc}
\hline \hline & \multicolumn{3}{c}{ Relative population density* } \\
\cline { 2 - 4 } Month & 1997 & 1998 & 1999 \\
\hline March & $15 \cdot 6$ & N.D. & N.D. \\
April & $8 \cdot 3$ & $10 \cdot 2$ & $7 \cdot 6$ \\
May & $4 \cdot 0$ & $1 \cdot 1$ & $4 \cdot 1$ \\
June & $7 \cdot 2$ & $14 \cdot 4$ & N.D. \\
July & $18 \cdot 0$ & $13 \cdot 4$ & $52 \cdot 3$ \\
August & $31 \cdot 5$ & $34 \cdot 1$ & $85 \cdot 0$ \\
September & $34 \cdot 5$ & $44 \cdot 5$ & $188 \cdot 3$ \\
October & $20 \cdot 0$ & $33 \cdot 5$ & N.D. \\
November & $35 \cdot 4$ & N.D. & N.D. \\
\hline \hline
\end{tabular}

* Population density was calculated as the number of voles trapped divided by trap hour $\times 10^{4}$.

N.D., Not done.

Table 3. The overall prevalence of infection with haemoparasites in male and female voles

\begin{tabular}{llll}
\hline \hline & $\begin{array}{l}\text { Males } \\
(n=218)\end{array}$ & $\begin{array}{l}\text { Females } \\
(n=202)\end{array}$ & Combined \\
\hline Haemobartonella $\mathrm{sp}$. & $65 \cdot 1$ & $60 \cdot 9$ & $63 \cdot 1$ \\
Bartonella grahamii & $23 \cdot 9$ & $31 \cdot 2$ & $27 \cdot 4$ \\
Hepatozoon erhardovae & $31 \cdot 2$ & $31 \cdot 7$ & $31 \cdot 4$ \\
Trypanosoma evotomys & $15 \cdot 1$ & $14 \cdot 9$ & $15 \cdot 0$ \\
Babesia microti & $1 \cdot 4$ & $0 \cdot 5$ & $1 \cdot 0$ \\
\hline \hline
\end{tabular}

but there was also a strong significant interaction between these factors $\left(F_{4,393}=12.090, P<0.001\right)$. Fig. 2 shows that mean species richness increased between spring and summer 1997 and then fell in the autumn. In 1998 mean species richness again began low and rose to peak in the summer, but this time stayed comparatively high in the autumn. In the final year of the study, mean species richness began

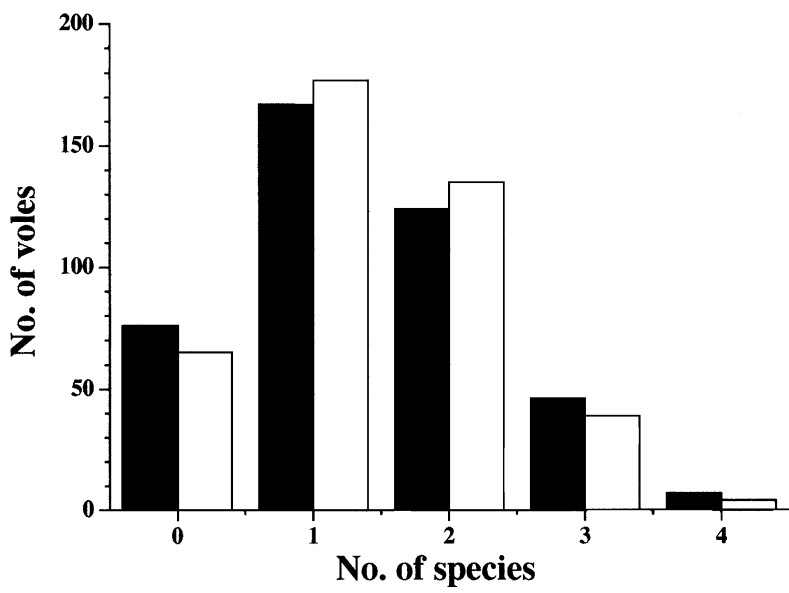

Fig. 1. Frequency distribution of infracommunity species richness. The observed data are in the filled columns and those predicted by the null model of Janovy et al. (1995) in the open columns. See text for full explanation and statistical analysis.

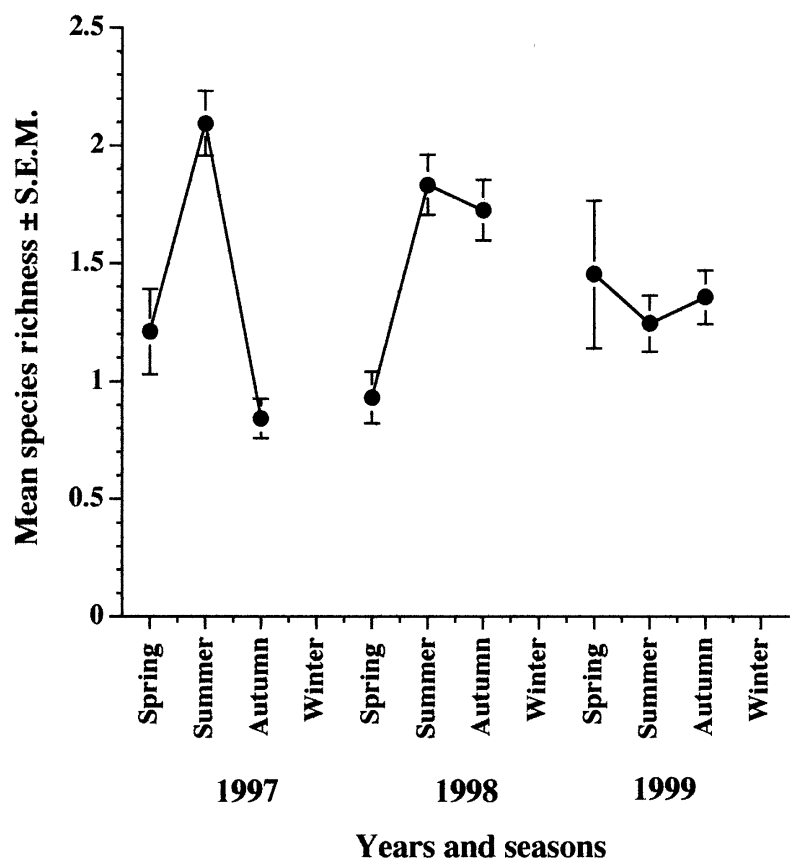

Fig. 2. Annual and seasonal changes in mean infracommunity species richness. See text for statistical analysis.

higher in the spring than in the 2 earlier years and there was little further change. Thus there were season-dependent changes in mean species richness, but the pattern of seasonal changes varied from one year to the next.

\section{Prevalence of species}

We analysed the influence of year, season, host sex and age on prevalence of infection by maximum likelihood methods, testing respectively models for each of the 5 species and the resulting minimum sufficient models are summarized in Table 4 . The age $\times$ sex interaction arose in each case because there were significant differences in the distribution of the 
Table 4. Minimum sufficient maximum likelihood statistical models of factors affecting the prevalence of infection

(For each species the interactions listed are significant and therefore form part of the final model.)

\begin{tabular}{|c|c|c|c|c|c|c|c|}
\hline \multirow[b]{2}{*}{ Species } & \multirow{2}{*}{$\begin{array}{l}\text { Principal interactions and } \\
\text { components in explaining } \\
\text { variation in data* }\end{array}$} & \multicolumn{3}{|c|}{ Test of individual effects } & \multicolumn{3}{|c|}{$\begin{array}{l}\text { Goodness of fit of min.suf. } \\
\text { model }\end{array}$} \\
\hline & & $x^{2}$ & D.F. & $P \uparrow$ & $\chi^{2}$ & D.F. & $P \ddagger$ \\
\hline Haemobartonella sp. & $\begin{array}{l}\text { Year } \times \text { season } \times \text { age } \times \text { infection } \\
\text { Sex } \times \text { age }\end{array}$ & $\begin{array}{r}20 \cdot 96 \\
6 \cdot 65\end{array}$ & $\begin{array}{l}8 \\
2\end{array}$ & $\begin{array}{l}0 \cdot 0073 \\
0 \cdot 0360\end{array}$ & $52 \cdot 04$ & 51 & $0 \cdot 43$ \\
\hline B. grahamii & $\begin{array}{l}\text { Year } \times \text { season } \times \text { infection } \\
\text { Year } \times \text { season } \times \text { age } \\
\text { Sex } \times \text { age }\end{array}$ & $\begin{array}{r}17 \cdot 90 \\
32 \cdot 34 \\
6 \cdot 65\end{array}$ & $\begin{array}{l}4 \\
8 \\
2\end{array}$ & $\begin{array}{l}0 \cdot 0013 \\
0 \cdot 0001 \\
0 \cdot 0360\end{array}$ & $69 \cdot 33$ & 69 & $0 \cdot 46$ \\
\hline H. erhardovae & $\begin{array}{l}\text { Year } \times \text { season } \times \text { se } \times \text { infection } \\
\text { Year } \times \text { season } \times \text { se } \times \text { age } \\
\text { Sex } \times \text { age } \times \text { infection } \\
\text { Season } \times \text { age } \times \text { infection } \\
\text { Year } \times \text { age } \times \text { infection }\end{array}$ & $\begin{array}{r}10 \cdot 98 \\
20 \cdot 58 \\
6 \cdot 13 \\
9 \cdot 85 \\
17 \cdot 20\end{array}$ & $\begin{array}{l}4 \\
8 \\
2 \\
4 \\
4\end{array}$ & $\begin{array}{l}0 \cdot 0268 \\
0 \cdot 0083 \\
0 \cdot 0465 \\
0 \cdot 0431 \\
0 \cdot 0018\end{array}$ & $24 \cdot 07$ & 24 & $0 \cdot 46$ \\
\hline T. evotomys & $\begin{array}{l}\text { Year } \times \text { season } \times \text { age } \\
\text { Sex } \times \text { age } \\
\text { Season } \times \text { infection }\end{array}$ & $\begin{array}{r}32 \cdot 34 \\
6 \cdot 65 \\
8 \cdot 19\end{array}$ & $\begin{array}{l}8 \\
2 \\
2\end{array}$ & $\begin{array}{l}0 \cdot 0001 \\
0 \cdot 0360 \\
0 \cdot 0166\end{array}$ & $79 \cdot 07$ & 75 & $0 \cdot 35$ \\
\hline B. microti & $\begin{array}{l}\text { Year } \times \text { season } \times \text { age } \\
\text { Sex } \times \text { age } \\
\text { Infection }\end{array}$ & $\begin{array}{r}32 \cdot 34 \\
6 \cdot 65 \\
537 \cdot 05\end{array}$ & $\begin{array}{l}8 \\
2 \\
1\end{array}$ & $\begin{array}{r}0 \cdot 0001 \\
0 \cdot 0360 \\
<0 \cdot 0001\end{array}$ & $52 \cdot 06$ & 77 & $0 \cdot 98$ \\
\hline
\end{tabular}

* Year - 3 levels (1997, 1998, 1999); season - 3 levels (spring, summer and autumn); age - 3 levels (age cohorts 1, 2 and 3 ); sex -2 levels (male and female), infection - 2 levels (infected or uninfected).

$\uparrow$ Probability that excluding the effect will make a significant change to the model.

$\ddagger$ Probability that the data do not differ significantly from the minimum sufficient model described by the principal interactions and components.

two sexes of voles among age classes. Similarly the year $\times$ season $\times$ age interaction indicated significant differences in the distribution of age classes between seasons and years.

For B. microti none of the factors entered into the analyses influenced prevalence. T. evotomys was only affected by season and these data are summarized in Fig. $3 \mathrm{C}$, where it can be seen that prevalence was at its lowest in the spring in all 3 years. Prevalence then rose to peak in the summer in 1997 and 1998, but continued to rise in 1999 to peak later, in the autumn.

Infections with $B$. grahamii also varied in relation to season but in addition there was a significant year effect. In Fig. $3 \mathrm{~A}$ the similarity in the seasonal pattern in 1997 and 1998 is clearly apparent with low prevalence in spring, a peak in the summer and a drop by the autumn. In 1999 there was a contrasting pattern with little change in prevalence across all three seasons.

Haemobartonella sp. yielded a more complex model with year, season and age all contributing to variation in the data as shown in Fig. 4. There was no consistent pattern of prevalence across the age classes. In some years and seasons the youngest mice showed low prevalence and the older classes higher prevalence (e.g. spring 1999). In others, the pattern was reversed (e.g. autumn 1997) and again in other years and seasons, all the age classes showed similar prevalence (e.g. summer 1999 and 1997). The only general conclusion to emerge from this analysis is that in 1998, prevalence was generally high across all seasons and age classes in comparision to other years.

$H$. erhardovae generated the most complex model, with all 4 factors contributing to interactions in various combinations. Essentially, prevalence varied among years and seasons, but also in relation to age and sex. We summarize the year $\times$ seasonal effects only in Fig. 3B. The greatest discrepancy in prevalence, between the years, was in spring and quite clearly overall prevalence was highest in 1999.

\section{Abundance of infection among infracommunities}

The frequency distribution of abundance of infection with B. grahamii was not well described by any of the distributions tested, but was closest to the negative binomial distribution $(k=0.146 \pm 0.0175, I=63.0$ and $D=0.862$ ). We analysed these data further after normalization (by $\log 10[x+1]$ transformation) by 4-way ANOVA in GLIM. This showed that the main effects of season and year were significant $\left(F_{2,409}=3 \cdot 422,0.05>P>0.025\right.$ and $F_{2,409}=3.931$, $0.025>P>0.01$, respectively) but there was also a significant 2-way interaction between year $\times$ age $\left(F_{4,399}=3.019,0.025>P>0.01\right)$. From Fig. $5 \mathrm{~A}$ it can be seen that in all 3 years mean abundance increased between spring and summer. In 1997 and 


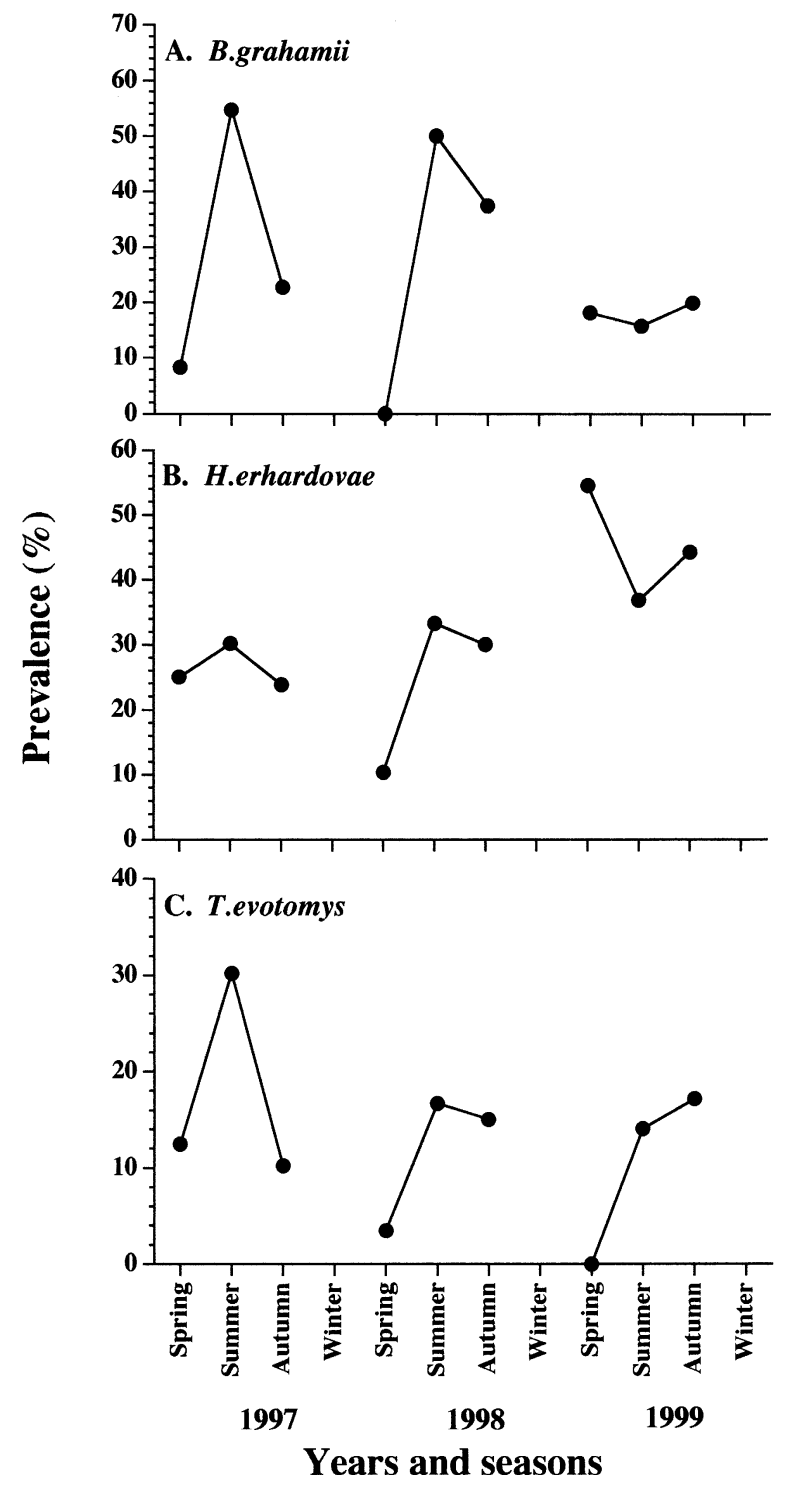

Fig. 3. Annual and seasonal changes in the prevalence of Bartonella grahamii, Hepatozoon erhardovae and Trypanosoma evotomys. See text for statistical analysis.

1998, but not in 1999, abundance then fell in the autumn.

Haemobartonella sp. also did not conform well to any of the distributions tested but again the discrepancy was least in the case of the negative binomial distribution $(k=1 \cdot 199 \pm 0 \cdot 169, I=2 \cdot 7$ and $D=0.596)$. Abundance was analysed further through a 4-way ANOVA in GLIM on $\log 10(x+1)$ transformed data. This revealed no significant main effects but there were some highly significant 2 - and 3 -way interactions (Table 5). Therefore variation in the abundance of Haemobartonella sp. was compounded by all 4 factors in varying ways and no clear picture emerged with respect to seasonal and annual trends.

The frequency distribution of $H$. erhardovae gave a good fit to the negative binomial distribution only $\left(\chi^{2}=8 \cdot 7\right.$, D.F. $=7, P=$ N.s., $k=0 \cdot 158 \pm 0 \cdot 018, I=$ $240 \cdot 8$ and $D=0 \cdot 861$ ). Analysis by 4 -way ANOVA in

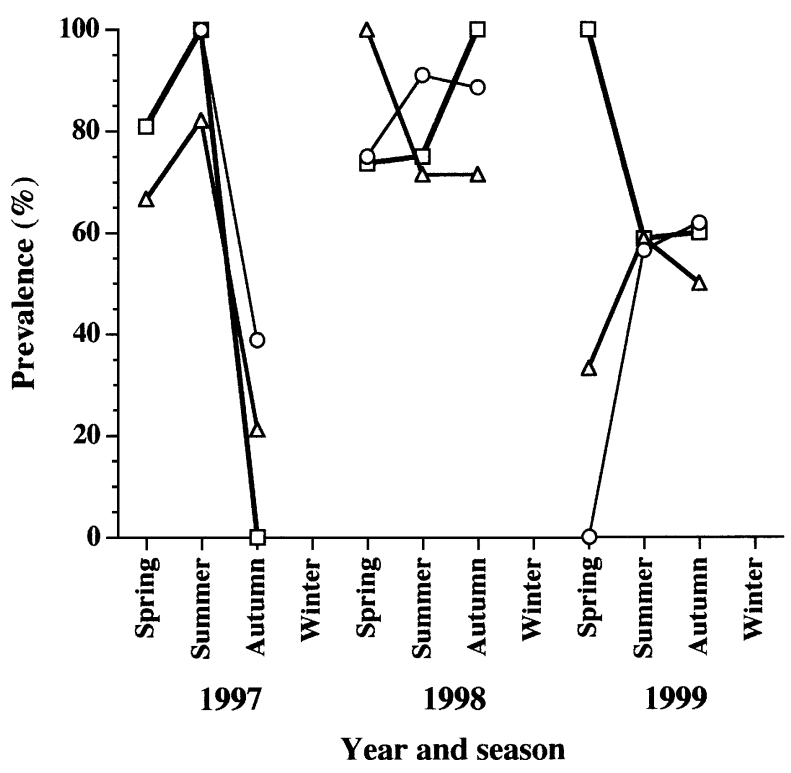

Fig. 4. Annual, seasonal and host age-related changes in the prevalence of Haemobartonella sp. $(\bigcirc)$ age class 1 ; $(\triangle)$ age class $2 ;(\square)$ age class 3 . See text for statistical analysis.

GLIM on $\log 10(x+1)$ transformed data indicated that abundance varied significantly between years (main effect of year $F_{2,409}=5.024, P<0.001$ ), but this was compounded by a year $\times$ season interaction $\left(F_{4,393}=3.428, \quad P<0.01\right)$. Fig. 5 B shows that seasonal changes in abundance were very similar in 1997 and 1998, but quite different in 1999, when the spring cohort of voles carried an unusually high abundance of infection. Perhaps surprisingly, there was no significant main effect of season but there were 2 significant 2-way interactions (year $\times$ age $F_{4,399}, \quad P=0.05 ; \quad$ season $\times \operatorname{sex} \quad F_{2,401}=4 \cdot 185$, $0.025>P>0.01)$ indicating additional discrepancies in relation to host sex and age.

Abundance of $T$. evotomys infection conformed well to the negative binomial distribution $\left(\chi^{2}=3 \cdot 2\right.$, D.F. $=4, P=$ N.S. $k=0.0728 \pm 0.011 ; I=7 \cdot 4$ and $D$ $=0.9225)$. These data were analysed by a 4-way ANOVA (GLIM with $\log 10(x+1)$ tranformed data) which revealed that only a single 2 -way interaction was significant (year $\times$ season, $F_{4,393}=3.877$, $P<0.005)$. Fig. 5 $\mathrm{C}$ shows that in 1997 abundance peaked in the summer, whereas in 1998 and 1999 peak abundance was recorded in the autumn. Despite the relatively high peak abundance in the autumn of 1999 , there was no significant main effect of year.

\section{Associations between parasites based on categorical data}

We tested the idea that any existing interactions between parasites should be reflected in co-occurrence or exclusion of species. In addition to data on the parasites (presence of infection/absence of infection) we also entered the 4 factors, year, season, host age and sex in a log-linear analysis, since these 


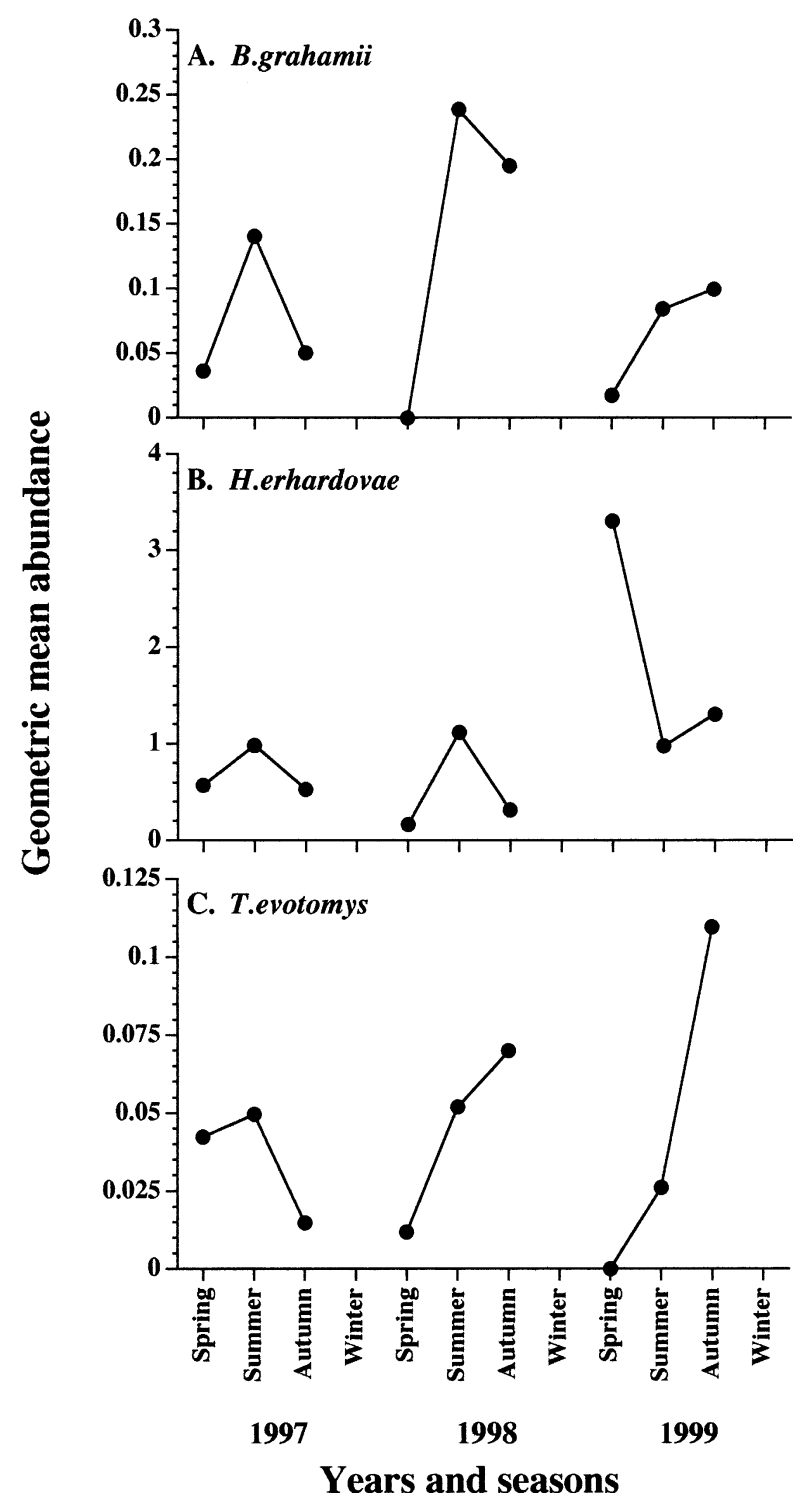

Fig. 5. Annual and seasonal changes in the abundance of infection with Bartonella grahamii, Hepatozoon erhardovae and Trypanosoma evotomys. Data are the geometric mean abundance in (A) no. of cells $/ 100$ erythrocytes, (B) no. of infected cells/100 leucocytes and (C) no. of parasites/100 erythrocytes. See text for statistical analysis.

had been shown earlier to influence the prevalence of the parasites in various ways. We tested a model with 9 factors, and this is summarized in Table 6. Only 4 terms in this model incorporated 2 sets of parasites each. The association between $B$. microti and $B$. grahamii arose because 3 of the $4 B$. microti infections were detected in voles that also carried B. grahamii, but this was the weakest term in the model. $H$. erhardovae and $T$. evotomys were also associated, (prevalence of $T$. evotomys in voles carrying $H$. erhardovae $=18.9 \%$, compared with $13.1 \%$ among voles without $H$. erhardovae). However, this association was year and age dependent and was also a weak term in the model. A stronger association was detected between $H$. erhardovae and Haemo- bartonella sp. (prevalence of Haemobartonella $\mathrm{sp} .=$ $67.4 \%$ among voles carrying $H$. erhardovae and $61.1 \%$ among those without), but again this was not a simple association and was dependent on season and age of the hosts. Finally, B. grahamii associated with Haemobartonella sp. (prevalence of Haemobartonella $\mathrm{sp} .=70.4 \%$ in voles with $B$. grahamii and $60.3 \%$ in those without) in a host sex and age dependent manner.

\section{Interactions between species based on quantitative data}

Interactions between species should be reflected in quantitative associations in hosts carrying both species. We first carried out a multiple correlation analysis on abundance data of 4 of the species in the study (excluding infection with $B$. microti because only 4 animals carried this species) using data only from animals that carried both species of each pair (Table 7). Because of the possible risk of Type I errors, we implemented the Dunn-Sidak correction and accordingly this allowed acceptance of just one of the 6 possible associations as significant, i.e. that between Haemobartonella sp. and B. grahamii (Fig. 6). However, it is worth noting that 3 of the associations involving $T$. evotomys also suggest some underlying quantitative interaction between the species involved (with Haemobartonella sp., $B$. grahamii and $H$. erhardovae).

Some of these relationships could have arisen as a consequence of differences in parasite burdens attributable to year, season, host age and sex effects. Therefore, to control for the possible bias arising out of the factors known to affect abundance of parasites, we next carried out a multiple correlation analysis on the residuals of each species, following minimum sufficient ANOVAs as described in the preceding section. Three associations had high correlation coefficients, but because of the Dunn-Sidak correction, we could only accept the association between Haemobartonella sp. and B. grahamii as significant (Table 7 and Fig. 6).

In a further approach we carried out a principal components analysis on the standardized residuals from each of the 5 ANOVAs. This gave approximately similar amounts of variation on each axis $(\mathrm{PCA} 1=30 \cdot 1, \mathrm{PCA} 2=25 \cdot 2, \mathrm{PCA} 3=23 \cdot 4, \mathrm{PCA} 4$ $=21 \cdot 3 \%$ ). Hence no further reduction of the data was possible.

\section{DISCUSSION}

This study constitutes the first comprehensive study of haemoparasites in a wild rodent population from north-east Europe. To our knowledge, apart from species identification (Sebek, 1978; Karbowiak \& Sinski, $1996 a, b)$, no other studies have reported on the component community structure of haemoparasites from this region nor have probed the 
Table 5. Statistical analysis of factors affecting abundance of infection $(\log 10[x+1]$ transformed data) with Haemobartonella sp. through a 4-way ANOVA with normal errors

(The full model deviance was $6 \cdot 7144$ with a scale parameter of $0 \cdot 01825$.)

\begin{tabular}{|c|c|c|c|c|c|}
\hline Source of variation & $\begin{array}{l}\text { Change in } \\
\text { deviance* }\end{array}$ & $\begin{array}{l}\text { Degrees of } \\
\text { freedom }\end{array}$ & $\begin{array}{l}\text { Scale } \\
\text { parameter }\end{array}$ & $\begin{array}{l}\text { Scaled } \\
\text { deviance } \uparrow\end{array}$ & $P$ \\
\hline Sex & $0 \cdot 0353$ & 1 & $0 \cdot 0211$ & $1 \cdot 6703$ & N.s. \\
\hline Age & $0 \cdot 1193$ & 2 & $0 \cdot 0213$ & $2 \cdot 8005$ & N.s. \\
\hline Season & $0 \cdot 1069$ & 2 & $0 \cdot 1069$ & $2 \cdot 5129$ & N.s. \\
\hline Year & $0 \cdot 0527$ & 2 & $0 \cdot 0211$ & $1 \cdot 2470$ & N.s. \\
\hline Age $\times \operatorname{sex}$ & $0 \cdot 0296$ & 2 & $0 \cdot 0211$ & $0 \cdot 7023$ & N.s. \\
\hline Season $\times$ age & $0 \cdot 0366$ & 4 & $0 \cdot 0211$ & $0 \cdot 4329$ & N.s. \\
\hline Season $\times \operatorname{sex}$ & $0 \cdot 0259$ & 2 & $0 \cdot 0213$ & $0 \cdot 6079$ & N.s. \\
\hline Year $\times$ age & $0 \cdot 7128$ & 4 & $0 \cdot 0213$ & $8 \cdot 3662$ & $<0 \cdot 001$ \\
\hline Year $\times \operatorname{sex}$ & $0 \cdot 0003$ & 2 & $0 \cdot 0197$ & $0 \cdot 0073$ & N.S. \\
\hline Year $\times$ season & $0 \cdot 3738$ & 4 & $0 \cdot 0198$ & $4 \cdot 7173$ & $<0 \cdot 001$ \\
\hline Year $\times$ season $\times$ age & $0 \cdot 2866$ & 6 & $0 \cdot 0191$ & $2 \cdot 5074$ & $0.025>P>0.01$ \\
\hline Season $\times \operatorname{sex} \times$ age & $0 \cdot 1225$ & 4 & $0 \cdot 0186$ & $1 \cdot 6465$ & N.s. \\
\hline Year $\times$ sex $\times$ age & $0 \cdot 0752$ & 4 & $0 \cdot 0185$ & $1 \cdot 0168$ & N.s. \\
\hline Year $\times$ season $\times \operatorname{sex}$ & $0 \cdot 1885$ & 4 & $0 \cdot 0185$ & $2 \cdot 5514$ & $0.05>P>0.025$ \\
\hline Year $\times$ season $\times$ sex $\times$ age & $0 \cdot 0243$ & 3 & $0 \cdot 0182$ & $0 \cdot 4464$ & N.s. \\
\hline
\end{tabular}

* Change in deviance following removal of combination specified in 'source of variation' column from the full factorial model. We begin by removing the 4-way interaction from the model. We then progressively remove the combinations in order from the base of the table towards the top. The main effect of year, was removed to assess the change in deviance but then replaced before removing the effect of season, and this was repeated for age and sex respectively.

$\uparrow$ Scaled deviance $=$ measure of contribution of factor specified under column labelled 'source of variation' to explaining variation in the data, calculated by fitting ANOVA with normal errors through GLIM. It is distributed as $F$. N.S., Not significant.

Table 6. Minimum sufficient maximum likelihood statistical model incorporating all factors quantified and all haemoparasitic species detected in the study

(Each line in the upper compartment represents a significant interaction that therefore forms part of the final model.)

\begin{tabular}{|c|c|c|c|c|c|}
\hline \multicolumn{3}{|c|}{ Principal interactions in explaining variation in data* } & \multicolumn{3}{|c|}{ Test of individual effects } \\
\hline Extrinsic factors & Intrinsic factors & Parasites & $x^{2}$ & D.F. & $P \uparrow$ \\
\hline \multirow[t]{2}{*}{ Year, season } & Sex, age & H. erhardovae & $16 \cdot 42$ & 8 & $0 \cdot 0368$ \\
\hline & Sex, age & B. grahamii, Haemobartonella sp. & $7 \cdot 52$ & 2 & $0 \cdot 0233$ \\
\hline Season & Age & H. erhardovae, Haemobartonella sp. & $10 \cdot 90$ & 4 & $0 \cdot 0277$ \\
\hline Year & Age & H. erhardovae, T. evotomys & $9 \cdot 97$ & 4 & $0 \cdot 0410$ \\
\hline Year, season & Age & Haemobartonella sp. & $20 \cdot 06$ & 8 & $0 \cdot 0101$ \\
\hline Year, season & & B. grahamii & $17 \cdot 36$ & 4 & $0 \cdot 0016$ \\
\hline \multirow[t]{2}{*}{ Year, season } & & T. evotomys & $9 \cdot 69$ & 4 & $0 \cdot 0461$ \\
\hline & & B. microti, B. grahamii & $3 \cdot 96$ & 1 & $0 \cdot 0467$ \\
\hline \multicolumn{3}{|c|}{$\begin{array}{l}\text { Goodness-of-fit of the minimum sufficient model specified by the } \\
\text { interactions listed above }\end{array}$} & $281 \cdot 8$ & 1535 & $1 \cdot 0 \ddagger$ \\
\hline
\end{tabular}

* Year - 3 levels (1997, 1998, 1999); season - 3 levels (spring, summer and autumn); age - 3 levels (age cohorts 1,2 and $3)$; sex -2 levels (male \& female), infection -2 levels (infected or uninfected).

$\uparrow$ Probability that excluding the effect will make a significant change to the model.

I Probability that the data do not differ significantly from the minimum sufficient model described by the principal interactions and components.

factors that structure such communities. Moreover, even in studies based elsewhere, the dynamics of these infections, and their mutual interactions, have seldom been evaluated comprehensively (Healing, 1981; Turner \& Cox, 1985) with quantifiable intrinsic and extrinsic factors taken into account simultaneously.
We recorded 5 species of haemoparasites in $C$. glareolus, all known to infect bank voles in other regions of Europe (Young, 1970; Baker, 1974; Turner, 1986; Walter \& Liebisch, 1980). Haemobartonella sp. was clearly the dominant (adjudged by prevalence) and $B$. microti an incidental species. Whilst total species richness in the bank voles was 5, 
Table 7. Analysis of quantitative associations between species

(Each test was carried out on voles carrying both species in the pair specified.)

\begin{tabular}{|c|c|c|c|c|c|}
\hline \multirow[b]{2}{*}{ Combination } & \multirow[b]{2}{*}{$n^{*}$} & \multicolumn{2}{|c|}{ Raw data } & \multicolumn{2}{|c|}{ Residuals§ } \\
\hline & & $r_{s} \dagger$ & $P \ddagger$ & $r_{s}$ & $P$ \\
\hline H. erhardovae $+T$. evotomys & 24 & $0 \cdot 42$ & $0 \cdot 044$ & $0 \cdot 34$ & $0 \cdot 10$ \\
\hline H. erhardovae + B. grahamii & 36 & $-0 \cdot 12$ & N.s. & $<0 \cdot 01$ & N.s. \\
\hline H. erhardovae + Haemobartonella $\mathrm{sp}$. & 88 & $-0 \cdot 02$ & N.s. & $0 \cdot 11$ & N.s. \\
\hline T. evotomys + B.grahamii & 20 & $0 \cdot 48$ & $0 \cdot 038$ & $0 \cdot 47$ & $0 \cdot 04$ \\
\hline T. evotomys + Haemobartonella $\mathrm{sp}$. & 43 & $0 \cdot 46$ & $0 \cdot 003$ & $0 \cdot 40$ & $0 \cdot 01$ \\
\hline B. grahamii +Haemobartonella $\mathrm{sp.}$. & 81 & $0 \cdot 41$ & $0 \cdot 0002$ & $0 \cdot 38$ & $0 \cdot 0007$ \\
\hline
\end{tabular}

* Number of voles carrying both species.

$\uparrow$ Spearman's Correlation Coefficient.

I Probability (2-tailed). Applying the Dunn-Sidak correction for multiple comparisons, we accept $P=0 \cdot 0085$ as the cutoff for rejecting the null hypothesis (Sokal \& Rohlf, 1981).

$\S$ Residuals from minimum sufficient ANOVAs in GLIM as explained in the text.

N.S., Not significant.
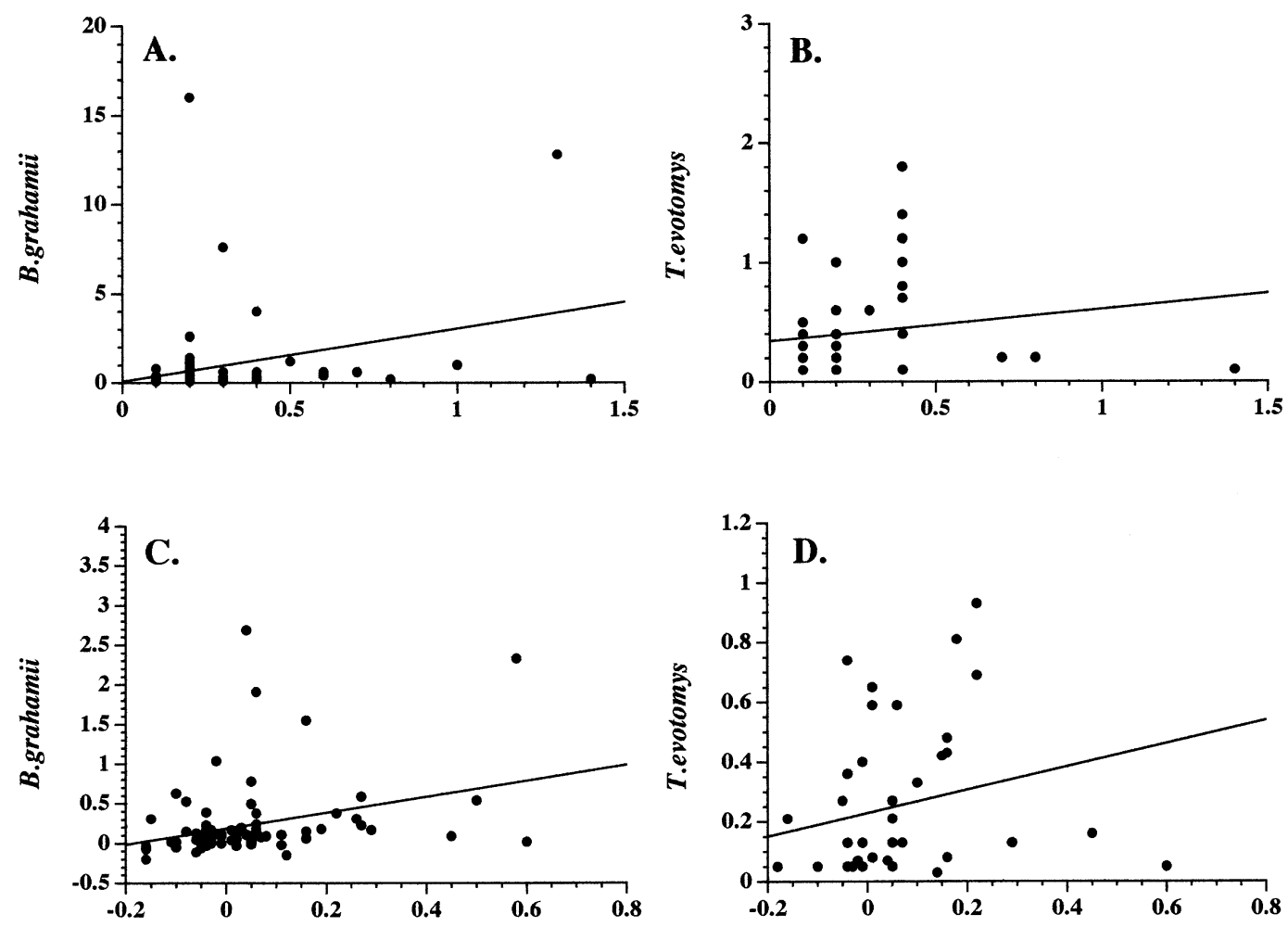

Haemobartonella sp.

Fig. 6. Positive association between the abundance of infection of Haemobartonella sp. with Bartonella grahamii, and with Trypanosoma evotomys. (A and B) Raw abundance data (units as in Fig. 5). (C and D) Residuals from minimum sufficient ANOVAs to control for the compounding effects of year, season, host sex and age. The lines are best-fit linear relationships fitted in Cricket Graph III, Version 1.5. See text for statistical analysis.

mean infracommunity species richness was $1 \cdot 4$, no animals carried all 5 species, and only 7 voles carried various combinations of 4 species. Perhaps surprisingly, neither age nor sex influenced mean species richness significantly but seasonal changes were apparent in 2 of the years. In 1998 there was little seasonal variation generating a statistically significant interaction, which explained more of the variation in the model than the relatively weak between-year difference. Thus, overall mean infra- community species richness remained relatively stable across the 3 years of our study.

Fluctuations in the prevalence and abundance of individual species of parasites were considerably more marked. Both prevalence and abundance of $T$. evotomys were highly season dependent and varied between the years, dropping low in two of the 3 years in the spring and then climbing to peak either in the summer or autumn. These observations concur with earlier work reporting marked reductions in preva- 
lence in the winter among voles in the UK (Young, 1970; Turner, 1986). T. evotomys belongs to the lewisi group of trypanosomes and is mainly transmitted by fleas (Molyneux, 1969). In experimental primary infections in voles parasitaemia is relatively short compared with other species, but can last for 3 weeks (Molyneux, 1969), sustained by reproducing amastigote stages in the spleen and lymphoid tissues (Molyneux, 1969). As with other related trypanosomes, it is likely that strong acquired immunity is a feature of the host-parasite relationship (Maraghi \& Molyneux, 1989; Albright \& Albright, 1991). Hence, we expected to see this species mainly in young animals, as found by Healing (1981), but the lack of a clear age effect in our study signifies that voles of all ages were exposed to infection and that many achieved maturity before becoming infected for the first time. Overall prevalence was $15 \%$, intermediate in comparison to prevalence rates reported by Sebek (1979), Healing (1981), Karbowiak \& Sinski (1996b) and that found by Turner (1986). In this part of Poland winters are severe (the ground may be frozen and covered by deep snow for months at a time) when it is likely that flea populations are less active, surviving only in the close confines of rodent nests. Such close proximity of vectors and hosts during the stressful winter period (and hence possibly with weakened immune systems) may have resulted in extended transmission between vector and host in those nests where infection was present. Consequently, any underlying age dependence in susceptibility to infection may have become occluded resulting in higher prevalence among older hosts than otherwise expected.

The ex-erythrocytic schizont stages of $H$. erhardovae reside in the lungs (Krampitz \& Haberkorn, 1988), where they can last for 7-9 months after initial infection (Krampitz, 1964). Since only gametocytes are quantifiable from blood, the real prevalence was probably much higher than reflected in our data. Both prevalence and abundance varied significantly from year to year and there were seasonal differences, but the overall pattern was complex and subject to host age and sex. It showed some similarity to that reported by Healing (1981), whose data suggest between-year differences but show no clear seasonal pattern, and contrasted with Young (1970) and Turner (1986), who found very marked seasonal patterns characterized by a sharp reduction in prevalence in the winter months. Whilst we were not able to sample rodents in the winter, a complex picture was generated in the 3 seasons that we monitored, in which the between-year effect was stronger than any underlying seasonal effect and compounded by sex- and age-based interactions.

Some species of Bartonella (B. baciliformis, $B$. quintana, B. henselae, B. elizabethae) are considered to be infective to humans (Birtles et al. 1995; Anderson \& Neuman, 1997) but B. grahamii (=
Grahamella sp.; Birtles et al. 1995), probably transmitted by fleas, is a parasite of rodents (Krampitz, 1962) in which it causes chronic infections lasting up to 120 days ('Tyzzer, 1942). In our study the abundance of $B$. grahamii varied significantly with seasons, increasing from a low in spring to peak in either summer or autumn, as found by Young (1970) and Turner (1986), but in contrast to the latter study the seasonal pattern varied between years.

Giemsa-stained blood smears do not allow confident distinction between some of the Anaplasmataceae. In all likelihood the organisms infecting our animals were Haemobartonella sp., but we cannot be totally confident about this. Several species have been described from other rodent hosts (e.g. H. muris musculi from Mus musculus (Schilling, 1928); H. microti from Microtus p. pennsylvaniucus (Tyzzer \& Weinman, 1939); $H$. arvicolae from $M$. arvali (Yakimoff, 1928 after Weinman, 1944)), but to our knowledge the Haemobartonella sp. infecting $C$. glareolus has not been characterized. We observed small round cocci, mostly orientated centrally on cells, although in $5 \%$ of cases marginal attachment on the edge of cells suggested that at least some were extracellular. Infections were generally low, with the highest recorded intensity being 16 parasitized cells/1000 erythrocytes, but the vast majority $(75 \cdot 1 \%)$ were $1-2$ parasitized cells/1000 erythrocytes with only 1 organism per cell. Our analysis revealed a complex situation and it was not possible to prioritize the relative importance of the influence of extrinsic and intrinsic factors on variation in Haemobartonella $\mathrm{sp}$. because only compound interactions were detected. Arthropod vectors transmit the Anaplasmataceae, and likely candidates in this region are fleas and lice (Weinman, 1944; Gothe \& Kreier, 1977) and hence cycles of transmission will inevitably be complex because of the different seasonal occurrence of these vectors.

Overall, perhaps the most surprising outcome of our analysis was the absence of any dominant role for intrinsic factors, particularly age, in structuring the component communities of haemoparasites in voles, albeit both sex and age contributed to some of the 2 and 3 -way interactions recorded. It may be relevant that earlier workers also disagreed about age-based patterns of prevalence: young voles (Healing, 1981), old voles (Turner, 1986) and voles of intermediate age (Young, 1970) have all been reported as showing high prevalence of $T$. evotomys in different studies. Similar disagreements are recorded for $H$. erhardovae and B. grahamii. However, consistent with our data, but contrasting with Young (1970), neither Turner (1986) nor Healing (1986) found any sex bias in prevalence of the parasites they monitored.

Since the frequency distribution of infracommunity species richness did not differ stat- 
istically from that predicted by a null model, the frequency of 2, 3 and 4 species co-infections was consistent with those expected from their respective prevalence rates. We conclude that at this level of analysis, our data did not support the existence of strong associations between species. Moreover, at the level of individual parasite species we found only weak support for interactions. B. grahamii with $T$. evotomys, reported earlier as co-varying (Turner \& Cox, 1985), did not do so in our study although a weak positive quantitative association (which we could not accept as significant without risking a Type I error) was evident. As reported by Young (1970), T. evotomys associated with H. erhardovae, but weakly and in a year and age-dependent manner. The latter species also showed a positive association with Haemobartonella sp., but in a season and agedependent manner and there was no support for a quantitative association of these species. The only combination which was convincingly supported by both prevalence (albeit in a sex and age-dependent manner) and quantitative data sets was that between B. grahamii and Haemobartonella sp. Both of these species are Anaplasmataceae and transmitted by arthropods, although little is known about their transmission dynamics and relationships with their vector hosts.

While our study was not designed specifically to relate host population size, or climatic changes, to parasite prevalence, some relationships are worth pointing out. The over-wintering population of voles was similar in each of the 3 years and fell further in May before peaking at varying levels in the summer. The relatively high density in the autumn of 1999 followed a long period of warm, relatively dry weather in the region. Interestingly, the rise in prevalence and abundance of $B$. grahamii, $H$. erhardovae and T. evotomys from winter to summer paralleled the increasing host populations in 1997 and 1998 but it was in 1999 that we observed the greatest contrast with other years (least apparent seasonal variation in mean infracommunity species richness and prevalence of $B$. grahamii). In contrast, H. erhardovae showed the highest prevalence in 1999 and a reversed pattern of seasonal occurrence. These contrasting patterns may have been related to fluctuations in host and vector populations and this will be worth exploring in future work.

The forest site in which our study was conducted has been relatively stable for about $70-80$ years and now comprises mature mixed woodland, known to be the preferred habitat of bank voles (Alibhai \& Gipps, 1985). However, this site borders closely on abandoned fields, which have lain fallow for 8 years and been allowed to revert to nature (since 1991, Rogozinska, 1997), with succession to woodland apparent throughout in the form of young, high and dense silver birch copses. The bank vole population in the woodland now has much more opportunity to expand, to mix with other vole populations (and to be exposed to infections from neighbouring populations) and the corridors of new woodland are likely to increase with each passing year if no intervention is implemented. The long-term consequences of the changing ecology of the region for parasitic infections are largely unknown, and therefore, it is all the more important to sustain the monitoring activities for the future.

Finally, this study, the first comprehensive analysis of the component community structure of haemoparasites in C. glareolus from NE Europe, has established the highly dynamic nature of the community with marked variation between years and seasons. These extrinsic factors, and their interaction, consistently explained the greatest proportion of the variation in our data. It is also pertinent that despite the underlying fluctuation in the prevalence and abundance of individual species, variation of infracommunity species richness was less marked with moderate seasonal fluctuations, and betweenyear differences, within a relatively narrow range. At this level the component community of haemoparasites in C. glareolus was therefore relatively stable, despite the changing environment on the periphery of our study site.

We are grateful to the British Council, UK and the State Committee for Scientific Research (KBN), Poland for financial support for this study (KBN Grants UM 855 and UM 930). We thank Dr R. Halba for making the facilities at the field station in Urwitalt available to us.

\section{REFERENCES}

ALbright, J. W. \& ALbRight, J. F. (1991). Rodent trypanosomes: their conflict with the immune system of the host. Parasitology Today 7, 137-140.

AlibHaI, s. K. \& GIPPS, J. H. W. (1985). The population dynamics of bank voles. In The Ecology of Woodland Rodents Bank Voles and Wood Mice. Symposia of the Zoological Society of London 55 (ed. Flowerdew, J. R., Gurnell, J. \& Gipps, J. H. W.), pp. 277-305.

Clarendon Press, Oxford.

ANDERSON, B. E. \& NEUMAN, M. A. (1997). Bartonella spp. as emerging human pathogens. Clinical Microbiology Reviews 10, 203-219.

BAKER, J. R., CHITTY, D. \& PHIPPS, E. (1963). Blood parasites of wild voles, Microtus agrestis, in England. Parasitology 53, 297-301.

BeHNKe, J. M., LEWIS, J. W., MOHD ZAin, S. N. \& GILbeRT, F. s. (1999). Helminth infections in Apodemus sylvaticus in southern England: interactive effects of host-age, sex and year on prevalence and abundance of infections. Fournal of Helminthology 73, 31-44.

BIRTLES, R. J., HARRISON, T. G., SAUNDERS, N. A. \& Molyneux, D. H. (1995). Proposal to unify the genera Grahamella and Bartonella, with descriptions of Bartonella talpae comb. nov., and three new species, Bartonella grahamii sp. nov., Bartonella taylorii sp. nov., and Bartonella doshiae sp. nov.. International Fournal of Systematic Bacteriology 45, 1-8. 
CRAWLey, M. T. (1993). GLIM for Ecologists. Blackwell Scientific Press, Oxford.

DASH, K. M., HALL, E. \& BARgER, I. A. (1988). The role of arithmetic and geometric mean worm egg counts in faecal egg count reduction tests and in monitoring strategic drenching programs in sheep. Australian Veterinary fournal 65, 66-68.

Elliott, J. M. (1977). Some Methods for the Statistical Analysis of Samples of Benthic Invertebrates.

Freshwater Biological Association, Cumbria, UK. Gothe, R. \& Kreier, J. P. (1977). Aegyptianella, Eperythrozoon and Haemobartonella. In Parasitic Protozoa, Vol. IV (ed. Kreier, J. P.), pp. 251-294. Academic Press, New York.

HEALING, T. D. (1981). Infections with blood parasites in small British rodents Apodemus sylvaticus, Clethrionomys glareolus and Microtus agrestis. Parasitology 83, 179-189.

JANOVY, J. Jr., CLOPTON, R. E., CLOPTON, D. A., SNYDER, S. D., EFTING, A. \& KREBs, L. (1995). Species density distributions as null models for ecologically significant interactions of parasite species in an assemblage. Ecological Modelling 77, 189-196.

KARBOWIAK, G. \& SINSKI, E. (1996a). The finding of Babesia microti in bank vole Clethrionomys glareolus in the district of Mazury Lakes (Poland). Acta Parasitologica 43, 50-51.

KARBOWIAK, G. \& SINSKI, E. (1996b). Occurrence and morphological characteristics of a Trypanosoma evotomys strain from North Poland. Acta Parasitologica 41, 105-107.

KARboWiak, G., STANKo, M., RYCHLIK, L., NOWAKOWSKI, W. \& SIUDA, K. (1999). The new data about zoonotic reservoir of Babesia microti in small mammals in Poland. Acta Parasitologica 44, 142-144.

KrampitZ, H. E. (1962). Weitere Untersuchungen an Grahamella, Brumpt, 1911. Zeitschrift fuer Tropenmedizin und Parasitologie 13, 34-53.

KRAMPITZ, H. E. (1964). Über das Vorkommen und Verhalten von Haemococcidien der Gattung Hepatozoon, Miller 1908 (Protozoa, Adeleida) in mittel-und südeuropäischen Säugern. Acta Tropica 21, 114-154.

KRAMPitZ, H. E. \& HABERKoRN, A. (1988). Experimental treatment of hepatozoon infections with anticoccidial agent toltrazuril. Fournal of Veterinary Medicine, $B$ 35, 131-137.

Maraghi, s. \& MOlyneux, D. H. (1989). Studies on cross-immunity in Herpetosoma trypanosomes of Microtus, Clethrionomys and Apodemus. Parasitology Research 75, 175-177.

MARGOlis, L., ESCH, G. W., HOLMES, J. C., KURIS, A. M. \& SCHAD, G. A. (1982). The use of ecological terms in parasitology (report of an ad hoc committee of The American Society of Parasitologists). Fournal of Parasitology 68, 131-133.

MAZURKiewicz, M. (1972). Density and weight structure of populations of the bank vole in open and enclosed areas. Acta Theriologica 34, 455-465.

Molyneux, D. H. (1969). The morphology and biology of Trypanosoma (Herpetosoma) evotomys of the bankvole, Clethrionomys glareolus. Parasitology 59, 843-857.
MORRIS, P. (1972). A review of mammalian age determination methods. Mammal Review 2, 69-104.

POulin, R. (1993). The disparity between observed and uniform distributions: a new look at parasite aggregation. International Fournal for Parasitology 23, 937-944.

ROGOZINSKA, M. (1997). Sukcesja w zgrupowaniu drobnych ssaków ugorowanego pola uprawnego. Stan w 4 late po rozpoczeciu ugorowania. (Changes in the population structures of small mammals on fallow fields, previously cultivated. Appraisal 4 years after the cessation of cultivation). M.Sc. thesis, Department of Ecology, University of Warszawa.

SANTOS-GOMez, G. M., abranches, P., Maraghis, S., Dirie, M. F., SILVA-PEREIRA, M. C., VALVERDE, D. \& MOLYNEUX, D. H. (1993). Laboratory and field studies on Herpetosoma trypanosomes from Portugal. Annales de Parasitologie Humaine et Comparée 68, 163-168.

SCHILling, v. (1928). Eperythrozoon coccoides, eine neue durch Splenectomie aktivierbare Dauerinfektion der weissen Maus. Klinische Wochenschrift 7, 1854-1855.

SEBEK, z. (1978). Blood parasites of small mammals in Western Hungary. Parasitologia Hungarica 11, 17-21. SEbeK, Z., Rosicky, B. \& SIXL, W. (1977). The occurrence of babesiasis affecting small terrestrial mammals and the importance of this zoonosis in Europe. Folia Parasitologica 24, 221-228.

SiNSKi, E. \& PAWEŁCZYK, A. (1999). Detection of reservoirs for Lyme borreliosis in the Mazury Lake district, Poland. Zentralblatt für Bakteriologie 289, 689-703.

SOKAL, R. R. \& ROHLF, F. J. (1981). Biometry, 2nd Edn. Freeman and Company, New York.

TURNER, C. M. R. (1986). Seasonal and age distributions of Babesia, Hepatozoon, Trypanosoma and Grahamella species in Clethrionomys glareolus and Apodemus sylvaticus populations. Parasitology 93, 279-289.

TURNER, C. M. R. \& COX, F. E. G. (1985). Interspecific interactions between blood parasites in a wild rodent community. Annals of Tropical Medicine and Parasitology 79, 463-465.

TYZZER, E. E. (1942). A comparative study of Grahamella, Haemobartonella and Eperythrozoa in small mammals. Proceedings of the American Philosophical Society 85, 359-398.

TYZZER, E. E. \& WEINMAN, D. (1939). Haemobartonella n.g. (Bartonella olim. pro parte). H. microti n. sp. of the field vole. American Fournal of Hygiene 30, 141-157.

WAlter, G. \& Liebisch, A. (1980). Studies of the ecology of some blood protozoa of mammals in north Germany. Acta Tropica 37, 31-40.

WigER, R. (1979). Seasonal and annual variations in the prevalence of blood parasites in cyclic species of small rodents in Norway with special reference to Clethrionomys glareolus. Holarctic Ecology 2, 169-175.

Wilson, K. \& GRENFELl, B. T. (1997). Generalized linear modelling for parasitologists. Parasitology Today 13, 33-38.

Weinman, D. (1944). Infectious anaemia due to Bartonella and related red cell parasites. Transactions of the Philosophical Society 33, 243-350.

young, A. s. (1970). Studies on the blood parasites of small mammals with special reference to piroplasms. Ph.D. thesis, University of London, UK. 